\title{
NACHRUF • OBITUARY • ELOGE
}

\section{In memoriam Gordon Roger Woodman}

\section{(22. September 1937 - 24. Oktober 2017)}

Am 24. Oktober 2017 verstarb unser langjähriges Mitglied, Herr Professor Dr. Gordon R. Woodman, in Birmingham, Großbritannien.

Gordon Woodmans Leben und akademisches Wirken war von seiner Beziehung zu Afrika und zum afrikanischen Recht geprägt. Unmittelbar nach seinem rechtswissenschaftlichen Studium an der Universität Cambridge, Großbritannien, zog es ihn 1961 nach Westafrika, wo er an der Universität von Ghana zunächst als Research Fellow und ab 1963 als Lecturer in Law tätig war. Hier bot sich ihm Gelegenheit, das traditionelle Bodenrecht Ghanas intensiv zu erforschen, das erste der vielen von ihm untersuchten Gebiete des afrikanischen Rechts, welches ihn zeitlebens faszinieren sollte. Daraus entstand die Grundlage für seine juristische Doktorschrift, ${ }^{1}$ mit der er 1966 in Cambridge promovierte. Zu dieser Zeit war er bereits Lecturer in Law an der Ahmadu Bello Universität in Nigeria, eine Position, der sich von 1967 bis 1976 Tätigkeiten als Lecturer in Law, Senior Lecturer in Law und Associate Professor in Law an der Universität von Ghana anschlossen. Seit 1976 lehrte er an der britischen Universität Birmingham, zuletzt bis zu seiner Emeritierung 2004 und darüber hinaus als Professor für Rechtsvergleichung. Gastprofessuren an Universitäten in Großbritannien, Malaysia, Mauritius, Österreich, Papua-Neuguinea, in den Vereinigten Staaten von Amerika und in der Karibik zeugen davon, wie sehr seine Lehre international geschätzt wurde. In Deutschland pflegte Gordon Woodman eine enge wissenschaftliche Kooperation mit der Rechts- und Wirtschaftswissenschaftlichen Fakultät der Universität Bayreuth, welche ihm 2006 in Anerkennung seiner Verdienste die juristische Ehrendoktorwürde verlieh.

Professor Woodman gehörte zweifellos zu den führenden Gelehrten des afrikanischen Rechts. Mehr als 200 Publikationen zu unterschiedlichen Rechtsbereichen - neben Recht in Afrika (insbesondere Bodenrecht, Ehe- und Familienrecht, Erbrecht, Verfassungsrecht, Recht der sozialen Sicherheit, Streitschlichtung, Juristenausbildung) sind dies vor allem solche auf dem Gebiet des Rechtspluralismus und der Rechtssoziologie - zeugen von seiner enormen Produktivität und Schaffensfreude. Sein breites wissenschaftliches Euvre entstand zwischen 1963 und 2015 und damit innerhalb einer Zeitspanne von mehr als einem halben Jahrhundert. Für seine herausragenden Arbeiten zum ghanaischen Recht wurde Professor Woodman von der Universität von Ghana 2008 die Ehrendoktorwürde ${ }^{2}$ und von der Republik Ghana 2016 die Auszeichnung Member of the Order of the Volta verliehen. Sein stets

1 Das Thema der Doktorschrift lautet: „The Development of Customary Land Law in Ghana.”.

2 D.Litt. honoris causa. 
geschätzter Rat fand auch in den Redaktionen zahlreicher wissenschaftlicher Zeitschriften Gehör, deren Mitglied er war, insbesondere dem Journal of Legal Pluralism and Unofficial Law, für das er von 1994 bis 2011 als Chefredakteur verantwortlich zeichnete. Als Präsident der Commission on Legal Pluralism amtierte er von 1984 bis 1990.

1993 wurde Gordon Woodman Mitglied der Gesellschaft für afrikanisches Recht. Schon zuvor besuchte er die Konferenzen unserer wissenschaftlichen Vereinigung und war in der Folgezeit stets gerngesehener Gast und aufmerksamer Gesprächspartner, zuletzt anlässlich der 40. Jahrestagung 2013 in Halle/Saale. Er trug auch als Autor ${ }^{3}$ zu den Publikationen unserer Gesellschaft bei und war als Redaktionsmitglied ${ }^{4}$ des Jahrbuchs für afrikanisches Recht an der letzten Ausgabe dieser Reihe beteiligt. Seine stets kenntnisreichen Vorträge und gelehrten Diskussionsbeiträge, in denen er sein profundes juristisches Wissen weitergab, sind den Konferenzbesucherinnen und -besuchern in guter Erinnerung. Darin kommt auch seine stete Bereitschaft zum Ausdruck, seine umfassenden Kenntnisse mit anderen zu teilen, um bei diesen das Wissen über afrikanisches Recht, Rechtspluralismus und Rechtssoziologie zu mehren.

Gerne nahm Professor Woodman daher auch in fortgeschrittenem Alter nach seiner Emeritierung die Rolle des Programmberaters am Tansanisch-deutschen Fachzentrum für Rechtswissenschaft (TGCL) ${ }^{5}$ in Daressalam, Tansania, ein. Anlässlich eines Interviews zu seinem achtzigsten Geburtstag gab er den juristischen Master- und Promotionsstudierenden am TGCL sein rechtswissenschaftliches Kredo durch die folgenden Worte mit auf dem Weg:

"I think what is important is to keep in mind the social consequences of law and of what they [i.e. the students] are doing as lawyers, and not to get too much absorbed in formalistic arguments. There is a tendency, particularly of practitioners, to be absorbed in formalities in order to win a case. But it is important for scholars to have a wider view on law. They should deal with the social implications and with the political implications of law." 6

Vor diesem Hintergrund sind das gesamte Wirken Professor Woodmans mit der bewundernswerten Breite seiner wissenschaftlichen Interessen und sein beeindruckendes Werk zu sehen, welches er uns hinterlässt. Wir werden ihn als einen guten Freund und stets hilfsbe-

3 Woodman, Gordon R., $21^{\text {st }}$ Annual Meeting of the African Law Association (Heidelberg, November 3 to 4, 1995), in: Jahrbuch für afrikanisches Recht 9 (1995), S. 199-201; Woodman Gordon R., Studies of African Law in Recent Meetings of the Commission on Folk Law and Legal Pluralism, in: Recht in Afrika 2 (1999), S. 225-227; Woodman, Gordon R., Accommodation Between Legal Cultures: The Global Encounters the Local in Ghanaian Land Law, in: Recht in Afrika 4 (2001), S. 57-75.

4 Jahrbuch für afrikanisches Recht 9 (1995).

5 Informationen zu diesem Fachzentrum sind unter www.tgcl.uni-bayreuth.de erhältlich.

6 Interview geführt von Ulrike Wanitzek am 22. September 2017, zur Veröffentlichung vorgesehen in: TGCL bulletin 2017. 
reiten Kollegen in dankbarer Erinnerung behalten. Die Gesellschaft für afrikanisches Recht wird Gordon Woodman ein ehrenvolles Andenken bewahren.

Harald Sippel und Ulrike Wanitzek 